ROCZNIKI PEDAGOGICZNE

Tom 13(49), numer $1-2021$

DOI: https://doi.org/10.18290/rped21131.6

\author{
KS. DARIUSZ STĘPKOWSKI \\ JOANNA LUDWIKA PĘKALA
}

\title{
NAUCZANIE ETYKI \\ Z PERSPEKTYWY KSZTAŁCENIA OGÓLNEGO
}

\section{WPROWADZENIE}

Pojęciu moralności przysługuje w refleksji pedagogicznej wyjątkowe miejsce. Według Johanna F. Herbarta tylko z jego pomocą da się wyrazić „jedyne i zupełne zadanie wychowania”, którym jest „estetyczne przedstawienie świata" (2008, s. 13). Wbrew pozorom w tym przedstawieniu Herbartowi nie chodziło o formowanie w podmiocie wychowania wrażliwości artystycznej ani smaku estetycznego, lecz kierował się do sprawców działania pedagogicznego i domagał się od nich, żeby brali pod uwagę (samo)kształcenie $^{1}$ jako własną aktywność powierzonych im dorastających. Jego zdaniem z tym idzie w parze skuteczność ich interwencji i to nie tylko tych odnoszących się do moralności, lecz również wszystkich pozostałych sfer rozwoju wychowanka (Stępkowski, 2010, s. 35-57; 2018a). Z uwagi na współcześnie szeroko rozpowszechnione tezy antypedagogiki należy $\mathrm{z}$ naciskiem dodać, że stosowanie się do postulatu Herbarta wcale nie kładzie kresu oddziaływaniom pedagogicznym, ale wprost przeciwnie - nadaje im właściwy sens, którym jest wspieranie wychowanka w (samo)kształceniu (Stępkowski, 2020).

Przywołane powyżej terminy: „moralność”, „(samo)kształcenie” i „wychowanie", nie tworzą przypadkowego układu. Na odwrót: wyznaczają

Ks. dr hab. DARIUSz STĘPKOwSKI, prof. UKSW - Wydział Nauk Pedagogicznych, Uniwersytet Kardynała Stefana Wyszyńskiego; adres do korespondencji: ul. Wóycickiego 1/3, 01-938 Warszawa; e-mail: d.stepkowski@uksw.edu.pl; ORCID: https://orcid.org/0000-0002-6855-1517.

Dr Joanna Ludwika PęKALA - Katedra Dydaktyki i Pedeutologii, Wydział Pedagogiczny, Uniwersytet Warszawski; adres do korespondencji: ul. Mokotowska 16/20, 00-561 Warszawa; e-mail: jpekala@uw.edu.pl; ORCID: https://orcid.org/0000-0003-4554-1962.

${ }^{1}$ Poniżej zostanie wyjaśniony ten nietypowy sposób zapisu. 
przestrzeń, w której dokonuje się to, co ma dla pedagogiki (nie tylko Herbartowskiej!) priorytetowe znaczenie - wychowanie i (samo)kształcenie moralne. W tym kontekście musi zastanawiać, że nauczanie etyki w polskich szkołach prowadzone jest od prawie trzech dekad w atmosferze sporu ideologicznego, który co prawda w ostatnim okresie nieco osłabł (Madalińska-Michalak, Jeżowski, 2017), jednak droga do rzeczowej dyskusji o możliwościach i formach edukacji moralno-etycznej w oświacie publicznej wciąż wydaje się daleka. Niewątpliwie utrudniły, jeżeli w ogóle nie uniemożliwiły to okoliczności, w których w 1990 roku etyka niespodziewanie znalazła się w programie kształcenia ogólnego w Polsce. Jak wiadomo wprowadzono ją jako erzac dla lekcji religii (Krukowski i in., 2014; Stępkowski i in., 2016, s. 38-41; Madalińska-Michalak i in., 2017, s. 31-39). W znacznej części polskiego społeczeństwa spowodowało to z góry nieprzychylny stosunek do tego przedmiotu. Nie oddziałało to też uskrzydlająco na dydaktykę etyki, która jeszcze kilka lat temu uchodziła - zdaniem Wandy Kamińskiej (2014, s. 19) - za nowy i dość mgliście zdefiniowany przedmiot wiedzy. W tym kontekście szczególnie niepokojące jest stwierdzenie, że: „Nikt nie pyta o swoistość etyki szkolnej" (Kamińska, 2014, s. 30).

Podejmując wyzwanie zawarte $\mathrm{w}$ powyższym stwierdzeniu, autorzy niniejszego tekstu przedstawiają lekcje etyki z perspektywy kategorii kształcenia ogólnego. Kategoria ta ma z jednej strony kluczowe znaczenie dla oświaty publicznej, gdyż kodyfikuje nauczanie i uczenie się w powszechnym systemie oświatowym, z drugiej jednak wymaga doprecyzowania z uwagi na swoją wieloznaczność. $Z$ tego względu w pierwszym punkcie zostanie udzielona odpowiedź na pytanie, czym jest kształcenie ogólne nie tylko jako kategoria dydaktyczna, lecz również ogólnopedagogiczna. W drugim punkcie przedstawiono dane odnośnie do dostępności lekcji etyki w polskich szkołach. Na zakończenie, w trzecim punkcie, uwaga autorów koncentruje się na koncepcji kształcenia ogólnego dla przedmiotu etyka, zawartej w aktualnie obowiązującej podstawie programowej kształcenia ogólnego dla szkół podstawowych i ponadpodstawowych. Przeprowadzone badanie ma za zadanie wyjaśnić przynajmniej w części, na czym polega swoistość szkolnych lekcji etyki prowadzonych w polskim systemie oświatowym.

\section{KSZTAŁCENIE OGÓLNE - CO TO TAKIEGO?}

Do przeprowadzenia niniejszego badania konieczne jest uprzednie wyjaśnienie kategorii kształcenia ogólnego. Nie spotyka się jej nazbyt często 
w opracowaniach dydaktycznych, nie mówiąc już o pedagogice ogólnej, w której zniknęło prawie bez śladu, podobnie jak termin „kształcenie”. Zwrotu „podstawa programowa kształcenia ogólnego" używa się w nomenklaturze administracji oświatowej do oznaczenia dokumentu pełniącego funkcję normatywną wobec wszystkich przedmiotów szkolnych nauczanych tak w oświacie publicznej, jak i niepublicznej.

Powodów marginalizacji kategorii kształcenia ogólnego należy - naszym zdaniem - doszukiwać się $\mathrm{w}$ dwóch procesach, które miały miejsce w pedagogice polskiej w drugiej połowie minionego stulecia i były ze sobą ściśle powiązane. Pierwszy dokonał się w pedagogice ogólnej i polegał na zrównaniu pojęcia kształcenia $\mathrm{z}$ wychowaniem, co przygotowało grunt pod przetransponowanie terminu „kształcenie” do dydaktyki (Stępkowski, 2018b, s. 46-56; 2019a, s. 14-22). Wskutek tego wyraz „kształcenie” kojarzy się współcześnie przede wszystkim z edukacją szkolną, formalną i nieformalną, a mówiąc dokładniej, z nauczaniem jako czynnością nauczyciela, na którą odpowiada uczeń przez uczenie się. Zgodnie z tym Wincenty Okoń pisze, że: „Kształcenie, obejmując wszelkie nauczanie i uczenie się [podkr. W.O.], stanowi odrębną w stosunku do innych zjawisk społecznych dziedzinę faktów" (1998, s. 9). Wydawać by się mogło, że z tego zdania wynika również odmienność kształcenia od wychowania. To przypuszczenie stoi jednak w skrajnej opozycji wobec intencji jego autora, który wychowaniu nie przyznaje samodzielnego statusu, lecz traktuje jako implicytny moment procesu nauczania-uczenia się, czyli kształcenia. Według W. Okonia (1998, s. 4) „rozwój życia duchowego uczniów, tudzież kształtowanie [...] ich świadomości oraz postaw i systemów wartości" są nieuniknionymi konsekwencjami właściwego doboru treści kształcenia i metod nauczania. To przekonanie wynika ze wspomnianej powyżej ideologizacji kształcenia, która dokonała się w pedagogice socjalistycznej i którą W. Okoń konsekwentnie wcielał w życie w obszarze dydaktyki (Stępkowski, 2019a, s. 66-70).

Ideologizacja i dydaktyzacja problematyki kształcenia spowodowały wykluczenie jej z dociekań pedagogiki ogólnej, skąd pierwotnie wywodzi się kategoria kształcenia ogólnego (Hessen 1997, s. 118-156). Należy z naciskiem podkreślić, że w zerwanej w Polsce przez socjalistyczną teorię wychowania tradycji myślenia ogólnopedagogicznego termin „kształcenie ogólne” odnosił się do „tworzenia” przez wychowanka swojej osobowości. W tym procesie oddziaływania wychowawcze stanowiły istotny, ale nie jedyny punkt odniesienia (Stępkowski, 2019a, s. 47-51). 
Ze wskazanych powyżej powodów kategorię kształcenia ogólnego spotyka się współcześnie prawie wyłącznie w dydaktyce. Używana jest w co najmniej trzech sensach. Pierwszy utożsamia się ze znaczeniem zwrotu „dydaktyka ogólna", który oznacza odrębną subdyscyplinę pedagogiczną zajmującą się kształceniem jako nauczaniem i uczeniem się (Bereźnicki, 2011; Bogaj, 2000; Okoń, 1967). Podstawą tego utożsamienia jest mylne - naszym zdaniem - przekonanie, że dla problematyki kształcenia obszarem właściwym jest dydaktyka.

Drugi sens denotuje nauczanie i uczenie się o specyficznym ukierunkowaniu - właśnie ogólnym. W przeciwieństwie do kształcenia zawodowego, kształcenie ogólne polega na ,zaznajamianiu uczniów z nagromadzonym przez ludzkość dorobkiem nauki, kultury i cywilizacji, najważniejszymi prawami rządzącymi rozwojem przyrody i życia społecznego, a ponadto na wyposażeniu dzieci i młodzieży w umiejętności teoretyczne i praktyczne niezbędne do życia we współczesnym świecie" (Kupisiewicz, 2005, s. 24; zob. także: Okoń, 1998, s. 65-78). Końcowy wynik tego procesu wyraża termin „wykształcenie ogólne”. Według Bogdana Suchodolskiego i Ireny Wojnar (1990, s. 64) powinno ono być ,indywidualnie zorganizowanym i przeżytym przyswojeniem systemu wiedzy, a nie jego mechanicznym odbiciem [...], nie encyklopedyczną mozaiką różnych nauk, lecz ich przemyślanym doborem, niezbędnym dla zrozumienia całokształtu życia”.

Żeby wyjaśnić trzeci i ostatni sens kategorii kształcenia ogólnego, należy odwołać się do Bogdana Nawroczyńskiego. W Zasadach nauczania wyodrębnił on trzy stadia dążenia do ideału wykształcenia. Pierwszym z nich jest kształcenie ogólne, czyli podstawowe. Polega ono na przekazie elementarnych wiadomości i umiejętności, dzięki którym uczący się będzie w stanie przejść do dwóch następnych stadiów - kształcenia zawodowego i kształcenia „rozszerzającego”, czyli naukowego (Nawroczyński, 1957, s. 117; zob. także: Stępkowski, 2019a, s. 52-54).

Z powyższych, z konieczności tylko skrótowych, rozważań wynika, że termin „kształcenie ogólne” denotuje dwa zagadnienia: po pierwsze, ideę ogólnodostępnej (publicznej) edukacji, która ma dostarczać wszystkim uczącym się podstawowej wiedzy i umiejętności niezbędnych do dalszego kształcenia, i, po drugie, kryterium doboru takich treści nauczania, które będą czerpać z dorobku przeszłości i równocześnie przyczyniać się do rozwijania u uczących się ich indywidualnych predyspozycji. Mimo że takiemu rozumieniu kształcenia ogólnego trudno odmówić racji, niewypowiedzianym jego założeniem jest transmisyjny model kształcenia. W modelu tym - mówiąc 
skrótowo - nauczyciel kształci, a uczeń kształci się. Zgodnie z tym między czynnościami oznaczonymi wyrazami „kształcić” i „kształcić się” zachodzi linearna zależność, którą $\mathrm{w}$ obiektywistycznych paradygmatach dydaktyki traktuje się jak przyczynę i skutek (Klus-Stańska, 2018, s. 59-109).

Linearne rozumienie związku między terminami „kształcić” i „kształcić się" przeczy całkowicie nie tylko polskiej tradycji myślenia ogólnopedagogicznego, lecz również genealogii wyrazu „kształcenie”. W języku polskim wyraz ten nie pochodzi wcale od rzemieślniczych czynności wyginania, formowania i nadawania kształtu, jak się dość powszechnie przyjmuje, lecz powstał dopiero w drugiej dekadzie XIX wieku do całościowego oznaczenia „reakcji” podmiotu na czynności wychowania, nauczania i socjalizowania (Stępkowski, 2019a, s. 31-35).

Przywracając polskiemu terminowi „kształcenie” właściwy sens, proponujemy oznaczyć nim czynności spełniane w związku z oddziaływaniami zewnętrznymi przez podmiot uczący się, których dokonuje on w sobie samym. Tylko na pozór może się wydawać, że takie uregulowanie łamie panujący w polskiej pedagogice zwyczaj językowy, zgodnie z którym za sprawcę kształcenia uważany jest przede wszystkim nauczyciel, a nie uczeń. Mamy jednak nadzieję, że powyżej udało nam się wyjaśnić źródła tego nieporozumienia.

Żeby podkreślić wkład, wnoszony przez podmiot w tworzenie własnej osobowości i równocześnie odciąć się od zdeformowanego sensu kształcenia jako celowego wywoływania zmian w uczącym się zgodnie z oczekiwaniami czy planem nauczającego (Niemierko, 2007, s. 18-26), posługujemy się zapisem ,(samo)kształcenie”. Oznacza on kształtowanie siebie samego przez odbiorcę oddziaływań pedagogicznych. Oczywiście (samo)kształcenie nie jest działaniem autarkicznym. Implikuje ono czynności, takie jak: opieka, wychowanie, czy nauczanie. Ich sprawcami są osoby dorosłe, na których spoczywa również pełna odpowiedzialność pedagogiczna. Głównym wyznacznikiem tej odpowiedzialności nie jest jednak wypełnienie (zleconych) zadań, lecz wywołanie w podmiocie „właściwych” reakcji, innymi słowy: chodzi o odpowiedź na pytanie, czy i na ile podjęte działania pedagogiczne skłoniły ich odbiorcę do (samo)kształcenia.

Afirmacja powyższej propozycji toruje drogę do dostrzeżenia w kategorii kształcenia ogólnego jeszcze jednego zagadnienia. Jest nim zasada integrowania czynności edukacyjnych - nauczania i uczenia się - i nieedukacyjnych - (samo)kształcenia (Benner, 2018). Zgodnie z tym ujęciem kategoria kształcenia ogólnego eksplikuje poszukiwanie możliwości takiej interwencji peda- 
gogicznej, która pomoże podmiotowi osiągnąć pożądane przez niego samego rezultaty $-\mathrm{z}$ jednej strony uczenie się, $\mathrm{z}$ drugiej (samo)kształcenie. Kwestia ta nie jest bynajmniej czymś nowym w dziejach myślenia pedagogicznego, jednak dopiero od dwóch stuleci stanowi eksplicytny przedmiot namysłu pedagogicznego. Bez wątpienia miało na to wpływ, z jednej strony, upowszechnienie się edukacji szkolnej, z drugiej zaś, rozniecona przez to nadzieja na bardziej sprawiedliwą dystrybucję szans rozwojowych wśród wszystkich dorastających.

Powyżej przedstawiono trzy sposoby odczytywania kategorii kształcenia ogólnego, które co prawda nakładają się na siebie, jednak mogą i powinny być rozróżniane w edukacji szkolnej: po pierwsze, kształcenie ogólne jako idea edukacji powszechnej i ogólnodostępnej, po drugie, kształcenie ogólne jako kryterium doboru treści nauczania i, po trzecie, kształcenie ogólne jako zasada integrowania czynności nauczania-uczenia się i (samo)kształcenia. Przez pryzmat tych trzech ujęć zostaną w kolejnych punktach niniejszego tekstu zbadane lekcje etyki w polskim systemie oświatowym ze względu na ich charakter ogólnokształcący. Na początku przedmiotem refleksji będzie udział dzieci i młodzieży w etyce szkolnej i związana z tym kwestia dostępności tego przedmiotu w edukacji publicznej.

\section{LEKCJE ETYKI \\ - OGÓLNODOSTĘPNE, DLATEGO OGÓLNOKSZTAŁCĄCE?}

Jeszcze do niedawna oszacowanie udziału dzieci i młodzieży w lekcjach etyki w szkołach publicznych w Polsce było rzeczą dość trudną. Ta sytuacja uległa zmianie w ostatnich latach, kiedy to ukazały się opracowania odnośnie do tego zagadnienia. Wśród nich warto wskazać na raport sporządzony na zlecenie Rzecznika Praw Obywatelskich pt. Dostępność lekcji religii wyznań mniejszościowych $i$ lekcji etyki $w$ ramach systemu edukacji szkolnej (Pawlik i in., 2015) i publikację poprojektową autorstwa Joanny Madalińskiej-Michalak, Antoniego J. Jeżowskiego i Szymona Więsława pt. Etyka $w$ systemie edukacji w Polsce (2017). Oba wykorzystaliśmy poniżej w celu określenia poziomu udziału dzieci i młodzieży w szkolnych lekcjach etyki². Ponadto odwołujemy się do danych statystycznych dostępnych na portalu

\footnotetext{
${ }^{2} \mathrm{~W}$ sprawie regulacji prawnych i sposobu organizowania lekcji etyki zob.: Zieliński (2014); Stępkowski i in. (2016, s. 38-41); Madalińska-Michalak i in. (2017, s. 32-39).
} 
internetowym „Etyka w Szkole” i w jednym z raportów Centrum Badania Opinii Społecznej (CBOS, 2019).

Wciąż czeka na opracowanie uczestnictwo uczniów w lekcjach etyki w okresie od początku nauczania tego przedmiotu w szkołach publicznych do połowy drugiej dekady nowego tysiąclecia. W odtworzeniu rzeczywistego stanu rzeczy jedną z poważniejszych trudności może stanowić - naszym zdaniem - niewiarygodność danych pochodzących z tego okresu. Z jednej strony bowiem władze oświatowe $z$ opieszałością reagowały na zgłaszaną przez rodziców/opiekunów chęć posyłania swoich dzieci/podopiecznych na zajęcia $\mathrm{z}$ etyki, a w przypadku uczniów pełnoletnich na wnioski o udział $\mathrm{w}$ takich zajęciach, $\mathrm{z}$ drugiej zaś propagujący etykę jako przedmiot alternatywny wobec religii publikowali wykazy szkół prowadzących etykę i liczby uczestniczących w nich uczniów, które były celowo zawyżane (Stępkowski i in. 2016, s. 44-46). Wydaje się, że zmianę w tym zakresie spowodowało Rozporzadzenie Ministra Edukacji Narodowej z dnia 25 marca 2014 roku (Dz. U. z 2014 r., poz. 478), w którym zobowiązano organy prowadzące szkoły do organizowania lekcji etyki każdemu uczniowi, choćby tylko jednemu. Wskutek tego nastąpił skokowy przyrost liczby szkół z etyką i uczniów na tych zajęciach.

W poniższej tabeli zestawiono liczbę szkół publicznych, w których w roku szkolnym 2014/2015 odbywały się lekcje etyki i w których nie było takich lekcji, z ogólną liczbą placówek edukacyjnych danego typu.

Tabela 1. Nauczanie etyki w szkołach publicznych w roku szkolnym 2014/2015

\begin{tabular}{|l|c|c|c|}
\hline \multicolumn{1}{|c|}{ Typ placówki edukacyjnej } & $\begin{array}{c}\text { Liczba placówek } \\
\text { z lekcjami etyki }\end{array}$ & $\begin{array}{c}\text { Liczba placówek bez } \\
\text { lekcji etyki }\end{array}$ & $\begin{array}{c}\text { Liczba placówek } \\
\text { ogółem }\end{array}$ \\
\hline Szkoła podstawowa & $1.119(9,06 \%)$ & $11.231(90,93 \%)$ & 12.350 \\
\hline Gimnazjum & $815(12,39 \%)$ & $5.758(87,61 \%)$ & 6.578 \\
\hline Zasadnicza szkoła zawodowa & $89(5,72 \%)$ & $1.468(94,28 \%)$ & 1.557 \\
\hline Liceum ogólnokształcące & $448(24,44 \%)$ & $1.385(75,56 \%)$ & 1.833 \\
\hline Ogółem $(100 \%)$ & $2.471(11,07 \%)$ & $19.842(88,93 \%)$ & 22.313 \\
\hline
\end{tabular}

Źródło: opracowanie własne na podstawie: Pawlik i in. (2015, s. 34).

W roku szkolnym 2014/2015 funkcjonowało w Polsce łącznie 22.313 szkół publicznych różnego szczebla (szkoły podstawowe, gimnazja, szkoły ponadgimnazjalne: zasadnicze szkoły zawodowe i licea ogólnokształcące). 
Lekcje etyki prowadzono w 11,07\% placówek. Najmniejszy odsetek odnotowano w zasadniczych szkołach zawodowych $-5,72 \%$, a największy w liceach ogólnokształcących $-24,44 \%$.

$\mathrm{Na}$ kolejnym schemacie przedstawiono zmiany, które dokonały się $\mathrm{w}$ zakresie upowszechnienia nauki etyki w publicznych placówkach oświatowych od roku szkolnego 2006/2007 do 2016/2017. W tym zestawieniu funkcję miernika pełni liczba szkół z lekcjami etyki i liczba etatów przeliczeniowych nauczycieli etyki ${ }^{3}$.

Schemat 2. Dynamika wzrostu liczby szkół z etyką i liczby etatów przeliczeniowych nauczycieli etyki

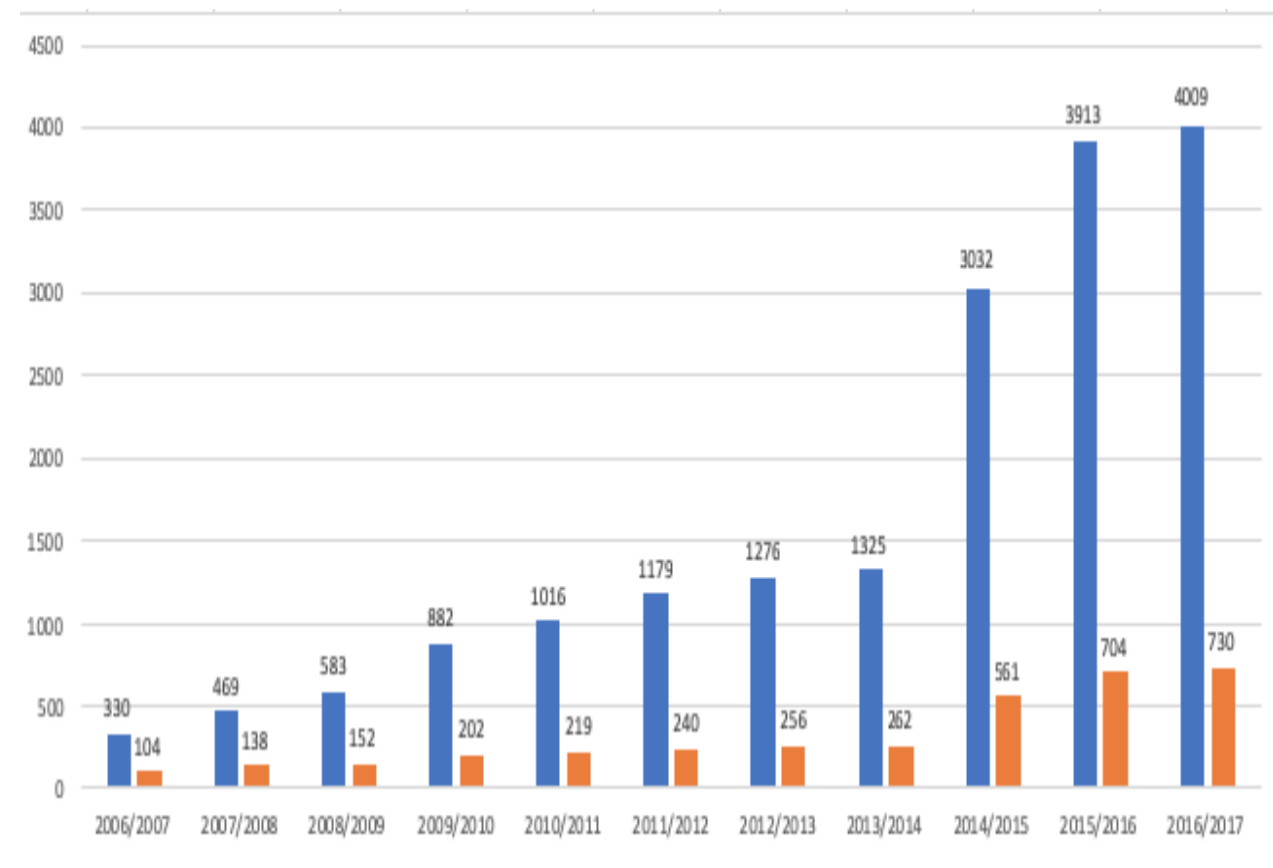

kolor niebieski - liczba szkół publicznych z etyką

kolor pomarańczowy - liczba etatów przeliczeniowych nauczycieli etyki

Źródło: opracowanie własne na podstawie: Madalińska-Michalak i in., 2017, s. 40-41 i portal internetowy Etyka w Szkole (b.r.).

\footnotetext{
${ }^{3}$ Etat przeliczeniowy to ogólna liczba godzin realizowanych w ramach lekcji etyki podzielona przez tygodniowe pensum dydaktyczne nauczyciela, czyli 18 godzin ,,przy tablicy”.
} 
Jak łatwo dostrzec na powyższym schemacie, raptowny wzrost liczby szkół z etyką nastąpił w roku szkolnym 2014/2015. Było ich o 128,8\% więcej niż rok wcześniej. Podobnie rzecz się ma z liczbą etatów przeliczeniowych nauczycieli etyki. $\mathrm{W}$ porównaniu $\mathrm{z}$ rokiem poprzedzającym ich liczba wzrosła o $114,1 \%$. Gdy porówna się liczebności obu tych mierników z rokiem szkolnym 2006/2007, to okazuje się, że przyrost szkół z etyką był dziewięciokrotny, natomiast liczba etatów przeliczeniowych nauczycieli etyki wzrosła pięciokrotnie. Co prawda w obu zakresach tendencja wzrostowa utrzymała się jeszcze w roku szkolnym 2015/2016, ale uzyskane przyrosty nie były już tak spektakularne. Liczebności szkół z etyką i etatów przeliczeniowych nauczycieli etyki podniosły się $\mathrm{w}$ stosunku do roku poprzedzającego odpowiednio o $29 \%$ i $25,5 \%$. Ten proces uległ jednak gwałtownemu zahamowaniu już w roku następnym - 2016/2017, kiedy to przybyło 96 szkół z etyką, co oznacza wzrost zaledwie o 2,5\% w stosunku do roku poprzedzającego, i 26 etatów nauczycieli etyki, czyli o 3,7\% więcej niż rok wcześniej.

Jak przedstawiają się prognozy na przyszłość, jeżeli chodzi o zainteresowanie etyką jako przedmiotem szkolnym, chcemy określić przez odwołanie do (jeszcze nie tak dawno) konkurencyjnych lekcji religii. Na kolejnym schemacie zrekonstruowano uczestnictwo uczniów szkół ponadgimnazjalnych w szkolnych lekcjach religii w okresie od 1991 do 2018 roku.

Schemat 3. Uczestnictwo uczniów szkół ponadgimnazjalnych w szkolnych lekcjach religii w okresie od 1991 do 2018 roku

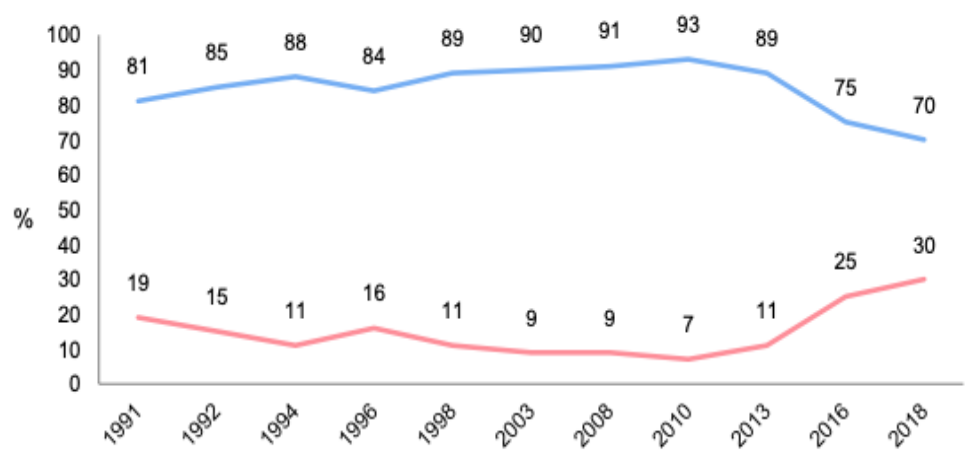

Źródło: CBOS, 2019, s. 161. Linia niebieska (górna) ilustruje wartości procentowe uczniów uczęszczających na lekcje religii w szkole, natomiast linia czerwona (dolna) wartości procentowe uczniów nieuczęszczających na te lekcje. 
Z powyższego schematu da się łatwo odczytać, że po 2010 roku systematycznie obniża się odsetek uczniów uczestniczących w szkołach $\mathrm{w}$ lekcjach religii. Jest to $\mathrm{w}$ pewnym sensie odwrócenie trendu panującego we wcześniejszym okresie, kiedy to odsetki te wzrastały, osiągając właśnie w roku 2010 maksymalną wartość 93\%. Począwszy od 2013 roku miernik ten drastycznie spada. W roku 2018 udział w lekcjach religii w szkołach deklarowało $70 \%$ uczniów.

Oczywiście kryzysu nauczania religii nie można odczytywać jako zapowiedzi wzrostu zapotrzebowania na lekcje etyki. W tym kontekście warto zwrócić uwagę na miernik umożliwiający statystyczne zdeterminowanie tego zapotrzebowania, który przyjęli w swoim badaniu Madalińska-Michalak i in. (2017). Opatrzyli go mianem dostępności. Jego wartość ustalono przez „liczbę uczniów przypadających przeciętnie na jedną lekcję etyki” (Madalińska-Michalak i in., 2017, s. 54). Autorom nie chodziło jednak o określenie rzeczywistej liczby uczniów biorących udział w pojedynczej jednostce lekcyjnej, lecz o oszacowanie liczby uczniów, która przypada w danym typie szkół publicznych i niepublicznych na statystyczną lekcję etyki w podziale na województwa. Nietrudno domyślić się, że tak zdefiniowana dostępność jest wprost proporcjonalna do upowszechnienia lekcji etyki. To z kolei powoduje, że województwa, w których niewielki odsetek rodziców/opiekunów (lub uczniów) zgłasza się do udziału w etyce, wykazują niski poziom dostępności (Madalińska-Michalak i in., 2017, s. 55-67; s. 70-82; s. 89-99).

W stronniczo wyliczonym poziomie dostępności bagatelizuje się status prawny lekcji etyki, które tak samo jak lekcje religii są w polskim systemie edukacyjnym nieobowiązkowe (do wyboru). Być może autorom przyświecało założenie, że ponieważ w badanych szkołach realizowany jest powszechny obowiązek szkolny (obowiązek nauki), to każdy z nauczanych w nich przedmiotów charakter ogólnokształcący. Naszym zdaniem jest to błąd myślowy, w którym mylnie utożsamia się ogólnodostępność danego przedmiotu z jego przynależnością do kategorii kształcenia ogólnego. Implikacja przebiega w odwrotnym kierunku - ponieważ dany przedmiot jest ogólnokształcący, dlatego powinien być ogólnie dostępny.

W następnym punkcie nasza uwaga skupia się na dwu pozostałych znaczeniach kategorii kształcenia ogólnego, tj. kryterium doboru treści kształcenia i zasadzie integrowania oddziaływań edukacyjnych i nieedukacyjnych. Przedmiotem analizy będą zapisy dotyczące nauczania etyki zawarte w obowiązującej obecnie podstawie programowej kształcenia ogólnego dla szkół podstawowych i ponadpodstawowych. 


\section{LEKCJE ETYKI - FILOZOFICZNE, DLATEGO OGÓLNOKSZTAŁCĄCE?}

Omówiona pod koniec poprzedniego punktu kwestia dostępności lekcji etyki zostałaby niewłaściwie odczytana, gdyby z powyższej krytyki czytelnicy wysnuli wniosek, że autorzy niniejszego tekstu są przeciwni tym lekcjom. Jest jednak zupełnie inaczej. Na podstawie wyników międzynarodowego badania ETiK-International, które przedstawił Stanislav Ivanov (2016), jesteśmy całkowicie przekonani, że nauczania etyki nie da się zastąpić innymi lekcjami, przykładowo religii, oraz że brak tego nauczania wcale nie wpływa pozytywnie na kompetencje moralno-etyczne uczniów. Te stwierdzenia mogą wydawać się oczywiste, ale przestają takimi być, gdy uwzględni się fakt, że coraz większy odsetek rodziców/opiekunów i samych uczniów, gdy osiągną pełnoletność, rezygnuje zarówno z lekcji etyki, jak i religii. Ten fakt powinien w najwyższym stopniu zaniepokoić pedagogów, gdyż powoduje ujawniającą się coraz wyraźniej lukę w zakresie kształcenia ogólnego młodego pokolenia, któremu po prostu brakuje kompetencji moralno-etycznych (Stępkowski i in., 2016, s. 46-53).

$\mathrm{Z}$ oczywistych względów nie jesteśmy w stanie przedstawić tutaj w szczegółach zapisów odnoszących się do nauczania etyki, które zawierają dwa rozporządzenia Ministra Edukacji Narodowej w sprawie podstawy programowej kształcenia ogólnego - jedno dla szkół podstawowych z roku 2017 (Dz.U. z 2017 r., poz. 356) i drugie dla szkół ponadpodstawowych z roku 2018 (Dz.U. z 2018 r., poz. 467). To powoduje, że poniżej ograniczymy się do wskazania w nich tylko tych elementów, które - naszym zdaniem - odnoszą się bezpośrednio do kategorii kształcenia ogólnego jako kryterium doboru treści kształcenia i jako zasady integrowania oddziaływań edukacyjnych (nauczania i uczenia się) i nieedukacyjnych ([samo]kształcenia).

W dokumencie dotyczącym szkoły podstawowej wyznaczono kształceniu ogólnemu trzynaście celów do zrealizowania. Większość z nich wiąże się z edukacją moralną, przykładowo: „1) wprowadzanie uczniów w świat wartości, w tym [uczenie - dop. autorzy] ofiarności, współpracy, solidarności, altruizmu, patriotyzmu i szacunku dla tradycji, wskazywanie wzorców postępowania i budowanie relacji społecznych, sprzyjających bezpiecznemu rozwojowi ucznia (rodzina, przyjaciele); [... 3) formowanie u uczniów poczucia godności własnej osoby i szacunku dla godności innych osób; [... 11) kształtowanie postawy otwartej wobec świata i innych ludzi, aktywności w życiu społecznym oraz odpowiedzialności za zbiorowość; [...] 13) ukierunkowanie ucznia ku wartościom" (Rozporzadzenie..., 2017, s. 11). 
W klasach 1-3 szkoły podstawowej nauczanie odbywa się w formie tzw. kształcenia zintegrowanego, a etyka stanowi jeden z trzynastu obszarów tego kształcenia, obok edukacji polonistycznej, edukacji matematycznej, edukacji społecznej $\mathrm{i}$ in. Treści nauczania w tym obszarze podzielono na dwie części: „Osiągnięcia w zakresie rozumienia podstawowych zasad i pojęć etyki (podkr. autorzy)” (Rozporzadzenie..., 2017, s. 52) i „Osiągnięcia w zakresie stosowania poznanych zasad (podkr. autorzy)" (Rozporzadzenie..., 2017, s. 53). Wskaźnikami umożliwiającymi ocenę, czy i na ile zamierzone kompetencje zostały osiągnięte, są tzw. czasowniki operacyjne, które opisują umiejętności ucznia.

W klasach 4-8 szkoły podstawowej nauczanie przybiera postać kształcenia przedmiotowego. Etyka odbywa się w formie lekcji. $Z$ uwagi na uczestniczących w nich uczniów mogą to być lekcje w jednym oddziale, lekcje międzyoddziałowe lub międzyklasowe.

Cele nauczania etyki zgrupowano w czterech obszarach tematycznych, a mianowicie: (1) kształtowanie wrażliwości aksjologicznej i refleksyjności, (2) tworzenie wypowiedzi, (3) kształtowanie postaw i (4) samokształcenie. $\mathrm{Na}$ uwage zasługuje stwierdzenie, że: „Etyka jako przedmiot nauczany w szkole podstawowej realizować ma przede wszystkim cele praktyczno-wychowawcze" (Rozporzadzenie..., 2017, s. 207). Na tej podstawie można przypuszczać, że podczas lekcji etyki w mniejszym stopniu chodzi o dociekania teoretyczne, a raczej o umiejętności praktyczne wynikające z refleksji nad problemami moralno-etycznymi. Warte podkreślenia jest również to, że autorzy podstawy programowej zdają sobie w pełni sprawę, że: „Wyrazem rozszerzania się sfery autonomii moralnej ucznia jest stopniowe interioryzowanie przez niego wartości i norm moralnych oraz pogłębiające się zrozumienie siebie jako podmiotu moralnego" (Rozporzadzenie..., 2017, s. 207). To powoduje, że „lekcje etyki mogą jedynie wspomagać ucznia w faktycznym realizowaniu tego kluczowego zadania; jego efektywna realizacja wymaga [...] decyzji samego ucznia, komplementarności oddziaływań edukacyjnych i wielu lat pracy ucznia nad sobą samym" (Rozporzadzenie..., 2017, s. 207).

W szkole ponadpodstawowej przypisuje się lekcjom etyki, podobnie jak na drugim etapie edukacyjnym szkoły podstawowej, przede wszystkim znaczenie praktyczne. Niemniej jednak następuje dalsze zaawansowanie treści kształcenia, co przejawia się w wyraźnym uwypukleniu teoretyczno-filozoficznego charakteru edukacji etycznej. Jak twierdzą twórcy podstawy programowej, dzięki powiązaniu obu tych wymiarów, tzn. praktyczno-wychowawczego i teoretyczno-filozoficznego, edukacja etyczna ma przyczyniać 
się do rozwijania w uczniach umiejętności myślenia moralno-etycznego, „którego istotą jest nieustanna interakcja między teoretyzowaniem (tym, co ogólne) a konkretnymi symulacjami i samym działaniem (tym, co szczegółowe)" (Rozporzadzenie..., 2018, s. 22).

Podobnie jak na drugim etapie edukacyjnym szkoły podstawowej, cele kształcenia zostały zgrupowane w cztery obszary. Opisują je następujące tytuły: „Tożsamość, podmiotowość i rozwój moralny”, „Wiedza o etyce”, „Tworzenie wypowiedzi” i „Samokształcenie” (Rozporzadzenie..., 2018, s. 324-325). Również zbieżnie z podstawą programową dla szkoły podstawowej wyliczono efekty (osiągnięcia), których oczekuje się od uczniów. Efekty te zawarte są w części zatytułowanej „Treści kształcenia - wymagania szczegółowe" (Rozporządzenie..., 2018, s. 325). Część ta została podzielona na dwa działy: „I. Elementy etyki ogólnej” (Rozporządzenie..., 2018, s. 325) i „II. Wybrane zagadnienia etyki szczegółowej (praktycznej, stosowanej, zawodowej)" (Rozporzadzenie..., 2018, s. 326).

Podsumowując, należy zwrócić uwagę, że lekcje etyki jako przedmiotu kształcenia ogólnego przybierają trzy postaci: (1) jeden z obszarów tematycznych kształcenia zintegrowanego w ramach edukacji wczesnoszkolnej, (2) wyodrębniony przedmiot nauczania o charakterze praktyczno-wychowawczym w starszych klasach szkoły podstawowej i (3) przedmiot o charakterze propedeutyki etyki filozoficznej w szkołach ponadpodstawowych. Każda $\mathrm{z}$ tych postaci różni się przesunięciem akcentu od zagadnień praktycznych przez praktyczno-teoretyczne po stricte teoretyczne. Tak więc można powiedzieć, że w podstawie programowej etyka została zaplanowana zgodnie z wymaganiami etyki filozoficznej. Do wiedzy pedagogicznej autorzy odwołują się tylko w tych fragmentach, w których chodzi o „praktyczne" zastosowanie treści filozoficznych lub sprawdzenie stopnia ich przyswojenia przez uczniów. Paradoksalnie może to służyć za wyjaśnienie, dlaczego większość nauczycieli etyki niczego nie chce zmieniać w podstawie programowej lub nie ma żadnego zdania na jej temat (Madalińska-Michalak i in. 2017, s. 214). To wyjaśnienie jest dość proste: dokumenty oświatowe tworzą ramy teoretyczno-dydaktyczne nauczania etyki (Kamińska, 2014, s. 20-21), natomiast rzeczywistość szkolna rządzi się swoimi własnymi prawami. Czy ten rozdźwięk nie powinien wzbudzać niepokoju co do jakości edukacyjnej i (samo)kształceniowej nauczania etyki w polskiej oświacie? W tym kontekście kategoria kształcenia ogólnego w obu analizowanych powyżej sensach, tj. jako kryterium doboru treści kształcenia i zasada integro- 
wania oddziaływań edukacyjnych i nieedukacyjnych, wydaje się fikcją istniejącą wyłącznie w podstawie programowej kształcenia.

\section{PODSUMOWANIE}

W polskim systemie oświatowym lekcje etyki funkcjonują od blisko trzech dziesięcioleci. Co prawda nauczanie etyki zalicza się do kształcenia ogólnego z racji umieszczenia go w podstawie programowej kształcenia ogólnego, jednak brakuje merytorycznej dyskusji na temat dydaktycznej konkretyzacji tego kształcenia i roli, jaką ma spełniać w edukacji szkolnej. Odnośnie do tego ostatniego powstaje pytanie, czy nauczyciele przedmiotowi mają jeszcze jakieś zobowiązania w zakresie moralnego (samo)kształcenia uczniów. To pytanie wydaje się retoryczne, gdyż celem edukacji publicznej jest kształcenie ogólne, a to implikuje (samo)kształcenie moralne, które nie dokonuje się wyłącznie na lekcjach etyki. Dzięki kategorii kształcenia ogólnego można - naszym zdaniem - właściwie zdefiniować miejsce i zadania nauczania etyki w szkole i równocześnie uniknąć sporu ideologicznego z religią, z którym ciągle jeszcze jest ono kojarzone.

\section{BIBLIOGRAFIA}

BENNER, D. (2008). Nieprzemijające znaczenie herbartowskiej koncepcji nauczania wychowującego. Horyzonty Wychowania, 7(13), 129-144.

BenNer, D. (2018). Pedagogika ogólna a pedagogika specjalna. Rozważania na temat związku między inkluzją i ekskluzją z perspektywy trzech przyczyn procesów wychowania i kształcenia. W: J. GoŁKowsKa, K. Sipowicz I. PATEJUK-MAZUREK (red.), Tradycja i współczesność pedagogiki specjalnej w tworzeniu spoteczeństwa dla wszystkich. W 95-lecie Akademii Pedagogiki Specjalnej im. Marii Grzegorzewskiej (s. 124-138). Warszawa: Wydawnictwo Akademii Pedagogiki Specjalnej.

BereźNICKI, F. (2011). Podstawy kształcenia ogólnego. Kraków: Oficyna Wydawnicza „Impuls”. BogaJ, A. (2000). Kształcenie ogólne. Między tradycją a ponowoczesnościa. Warszawa: IBE.

CBOS (2019). Młodzież 2018, red. M. Grabowska, M. Gwiazda. Warszawa.

Etyka w szkole (b.r.). Portal internetowy. Dostępny na: https://www.etykawszkole.pl/ (dostęp: 21.12.2019).

HeSSEN, S. (1997). O sprzecznościach i jedności wychowania. Warszawa: Wydawnictwo Akademickie ,Żak”.

IVANOv, S. (2016). Wstępna międzynarodowa walidacja Testu Kompetencji Moralno-Etycznej Piętnastolatków. Forum Pedagogiczne, 7(2/1), 117-125. DOI: https://doi.org/10.21697/ 10.21697/ fp.2016.2.07. 
KAMIŃSKA, W. (2014). Metodologiczna konstrukcja dziedziny dydaktyki etyki. Warszawa: Wydawnictwo Uniwersytetu Kardynała Stefana Wyszyńskiego.

Klus-StańsKa D. (2018). Paradygmaty dydaktyki. Myśleć teoria o praktyce. Warszawa: Wydawnictwo Naukowe PWN.

Krukowski, J., Sobczyk, P., Poniatowski M. (red.) (2014). Religia i etyka w edukacji publicznej. Warszawa: Wydawnictwo Uniwersytetu Kardynała Stefana Wyszyńskiego.

KuPISIEWICZ, Cz. (2005). Podstawy dydaktyki. Warszawa: WSiP.

MAdAliŃSKA-MichalaK, J., JEŻowSKI, A. (2017). Etyka i religia jako przedmioty nauczania: konkurencyjność czy komplementarność? Forum Oświatowe, 30(2), 219-241. Dostępny na: http://forumoswiatowe.pl/index.php/czasopismo/article/view/655 (dostęp: 10.10.2019).

Madalińska-Michalak, J., Jeżowski, A.J., WięSŁaw, Sz. (2017). Etyka w systemie edukacji $w$ Polsce. Warszawa: Wolters Kluwer.

NAWROCZYŃSKI, B. (1957). Zasady nauczania. Wrocław: Zakład Narodowy im. Ossolińskich.

Niemierko, B. (2007). Kształcenie szkolne. Podręcznik skutecznej dydaktyki. Warszawa: Wydawnictwa Akademickie i Profesjonalne.

OKоŃ, W. (1967). Podstawy wyksztatcenia ogólnego. Warszawa: Nasza Księgarnia.

ОкоŃ, W. (1998). Wprowadzenie do dydaktyki ogólnej. Warszawa: Wydawnictwo „Żak”.

PAWlik, W., Sobolewski, W., ŻurkowsKa, D. (2015). Dostępność lekcji religii wyznań mniejszościowych i lekcji etyki w ramach systemu edukacji szkolnej. Analiza i zalecenia. Biuletyn Rzecznika Praw Obywatelskich, 6. Dostępny na: https://www.rpo.gov.pl/ites/ default/files/BIULETYN\%20RZECZNIKA\%20PRAW\%20OBYWATELSKICH\%202015\%2 0nr\%206.pdf (dostęp: 16.06.2019).

Rozporządzenie Ministra Edukacji Narodowej z dnia 14 lutego 2017 r. w sprawie podstawy programowej wychowania przedszkolnego oraz podstawy programowej kształcenia ogólnego dla szkoły podstawowej, w tym dla uczniów $\mathrm{z}$ niepełnosprawnością intelektualną $\mathrm{w}$ stopniu umiarkowanym lub znacznym, kształcenia ogólnego dla branżowej szkoły I stopnia, kształcenia ogólnego dla szkoły specjalnej przysposabiającej do pracy oraz kształcenia ogólnego dla szkoły policealnej, Dz.U. z 2017 r., poz. 356.

Rozporządzenie Ministra Edukacji Narodowej z dnia 25 marca 2014 r. zmieniające rozporządzenie w sprawie warunków i sposobu organizacji nauki religii w publicznych przedszkolach i szkołach, Dz. U. z 2014 r., poz. 478.

Rozporządzenie Ministra Edukacji Narodowej z dnia 30 stycznia 2018 r. w sprawie podstawy programowej kształcenia ogólnego dla liceum ogólnokształcącego, technikum oraz branżowej szkoły II stopnia, Dz.U. z 2018 r., poz. 467.

STĘPKOWSKI, D. (2010). Pedagogika ogólna i religia. (Re)konstrukcja zapomnianego wątku na podstawie teorii Johanna F. Herbarta i Friedricha D. E. Schleiermachera. Warszawa: Wydawnictwo Naukowe Franciszka Salezego.

STĘPKOWSKI, D. (2018a). Shaping of Morality under School Conditions: Herbart and beyond. Scientia et Eruditio, 2, 1-13. DOI: https://doi.org/10.31262/2585-8556/2018/2/2/1-13.

STĘPKOWSKI, D. (2018b). Kształcenie ogólne - wizja pedagogiczna czy utopia? W sprawie translokacji teorii kształcenia ogólnego w powojennym dyskursie pedagogicznym w Polsce. Polska Myśl Pedagogiczna, 1(4), 31-58. DOI: https://doi.org/10.4467/24504564PMP.18.002.8641. 
STĘPKOWSKI, D. (2019). (Wy)kształcenie w polskiej pedagogice ogólnej. Prolegomena do historii pojęcia. W: K. MALISZEWSKI, D. STĘPKOWSKI, B. ŚLIWERSKI, Istota, sens i uwarunkowania (wy)kształcenia (s. 13-72). Kraków: Oficyna Wydawnicza „Impuls”.

StĘPKOWSKI, D. (2020). Kształcenie - widzenie - moralność. Herbarta aistetyczne podstawy edukacji moralnej. Forum Oświatowe 32(1), 37-56. DOI: https://doi.org/10.34862/fo.2020.1.3.

Suchodolski, B., Wojnar, I. (1990). Kierunki i treści ogólnego kształcenia człowieka. Warszawa-Kraków: Państwowe Wydawnictwo Naukowe.

ZIELIŃSKI, T.J. (2014). Nauka etyki w szkołach publicznych w ujęciu prawnym. W: J. KRUKOWSKi, P. SobCZYK, M. PONIATOwSKi (red.), Religia i etyka w edukacji publicznej (s. 95-120). Warszawa: Wydawnictwo Uniwersytetu Kardynała Stefana Wyszyńskiego.

\section{NAUCZANIE ETYKI Z PERSPEKTYWY KSZTAŁCENIA OGÓLNEGO}

\section{STRESZCZENIE}

Lekcje etyki funkcjonują w polskim systemie oświatowym od blisko trzech dekad. Autorzy przeprowadzają ich analizę ze względu na trzy sensy kategorii kształcenia ogólnego: jako idei edukacji ogólnodostępnej, jako kryterium doboru treści nauczania i jako zasady integrowania działania edukacyjnego i nieedukacyjnego - (samo)kształceniowego. Na tej podstawie wysuwają postulat refleksji nad edukacją moralno-etyczną w szkole, której tylko jedną z części są/mogą być lekcje etyki.

Słowa kluczowe: kształcenie ogólne; etyka; edukacja; polski system oświatowy.

\section{ETHICS TEACHING FROM THE PERSPECTIVE OF GENERAL EDUCATION}

\section{SUMMARY}

Ethics teaching has been functioning in the Polish educational system for nearly three decades. The authors conduct its analysis due to three senses of the general education category: as an idea of public education, as a criterion for the selection of teaching content and as a principle of integrating educational and non-educational activities. On this basis, they postulate reflection on moral and ethical education at school, of which only one part is/can be ethics teaching.

Keywords: general education; ethics; education; Polish educational system. 